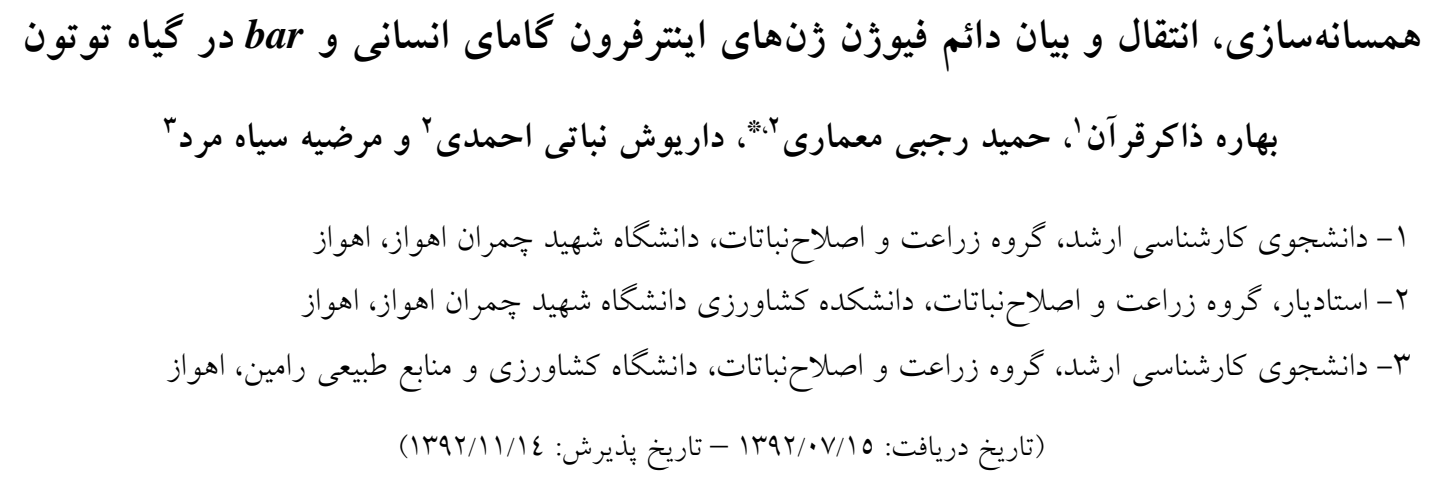

جكيده توليد يُروتئين ايتترفرون كاماى انسانى در سيستمهاى بيانى يوكاريوتى، بهعنوان يك يُروتئين نوتركيب درمانى، در مطالعات

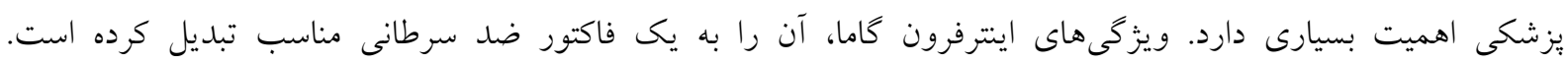

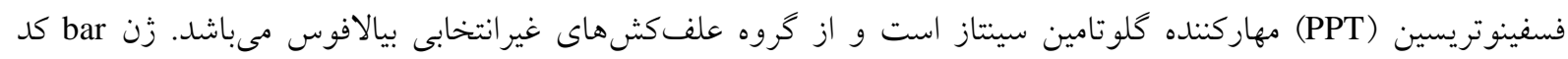

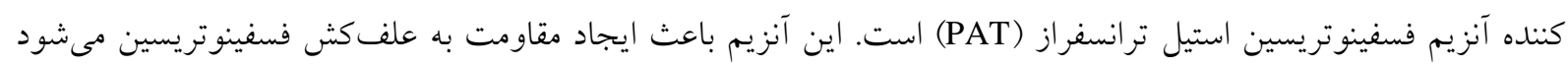

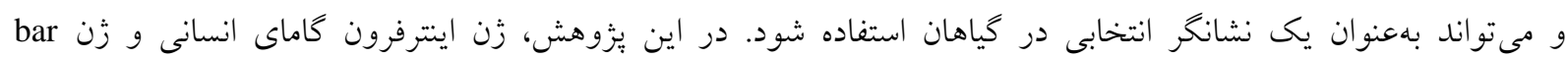

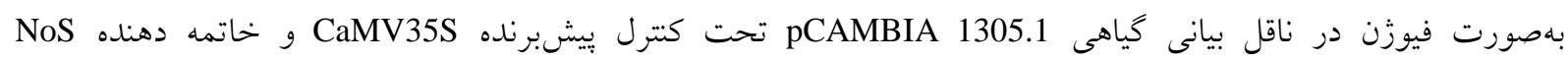

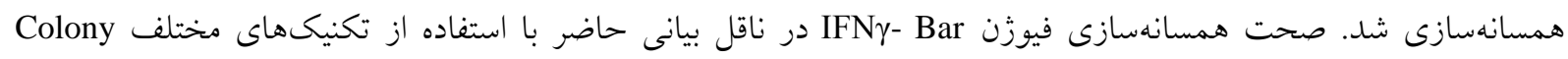

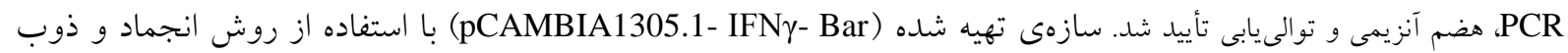

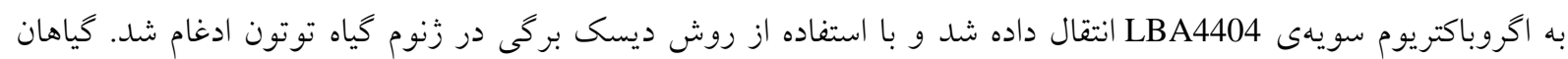

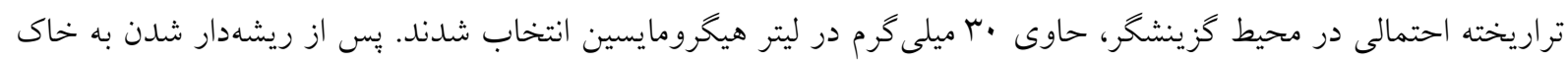

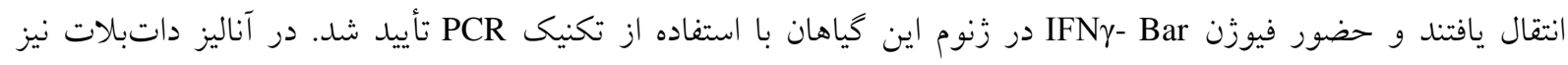
حضور يروتئين IFN واز گان كليدى: اينترفرون كاماى انسانى، بيان دائم، گياه توتون، زن bar 
نبود و بنهور مشابه، بازده بيان اينترفرون كاماى انسانى در

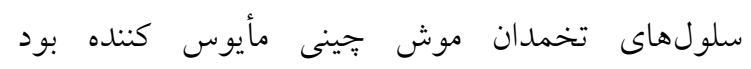

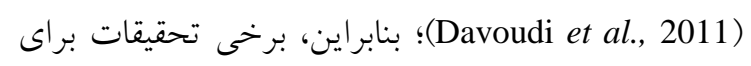

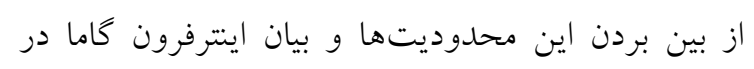

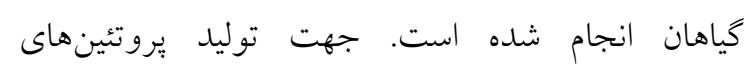
نوتركيب كياهان در مقايسه با سيستمهاى سنتى مزاياى

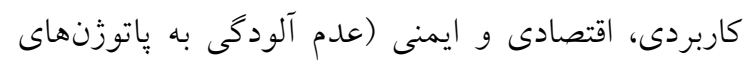

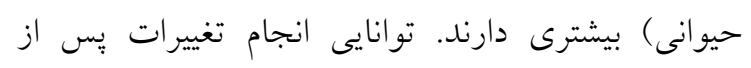

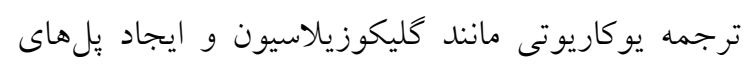
دىسولفيدى كه اغلب براى فعاليت بيولوزيكى بسيارى از

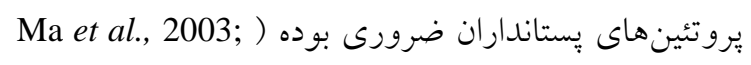

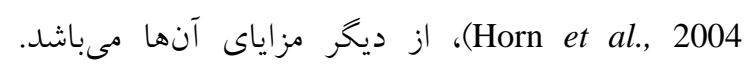
همسانهسازى و بيان زن اينترفرون گاماى انسانى در بذور

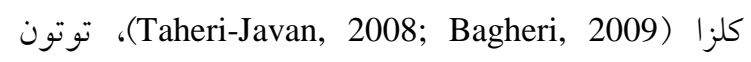
و همجنين در كشت سلولى (Azhdari, 2009) سوسيانسيون برنج (Chen et al., 2004) با موفقيت انجام شده است.

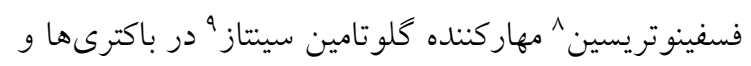

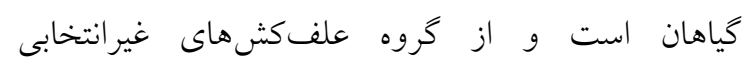

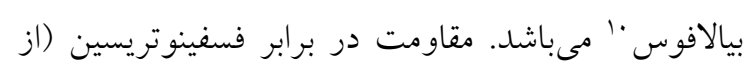

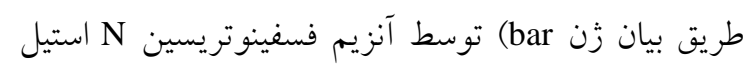

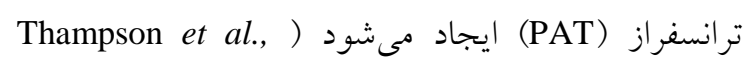

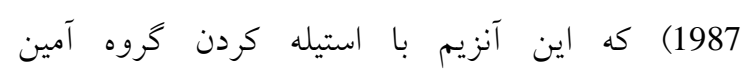
فينو 1987) اولين بار از Streptomyces hygroscopicus جداسازى شده است. در مقايسه با نشانكرهاى مقاوم به آنتىبيوتيك،

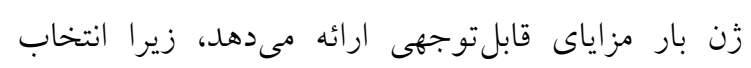

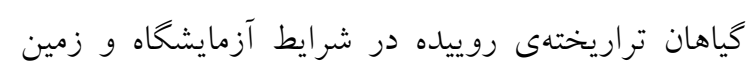

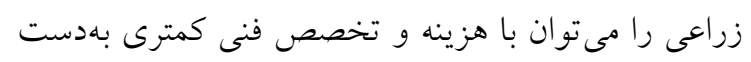

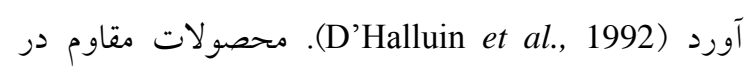
برابر علف كش توسط بيان زن بار در ذرت (م)

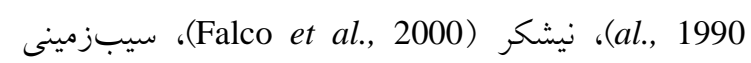

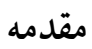

اينترفرون گاما يك بروتئين مهم دارويى است. ايتترفرونها

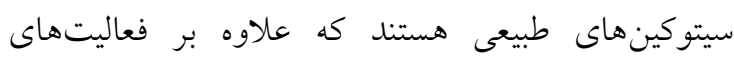

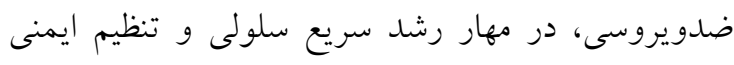

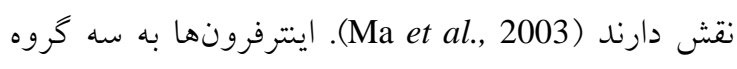

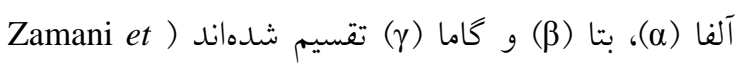

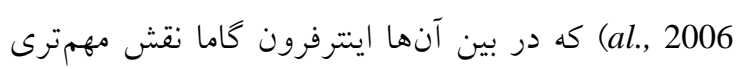
در تنظيم ايمنى دارد. اين كليكويروتئين محصول فعاليت

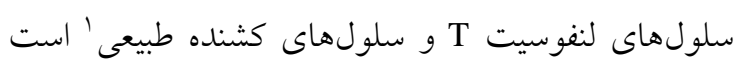

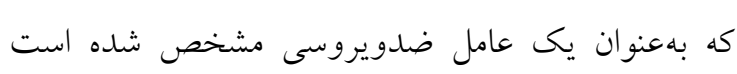

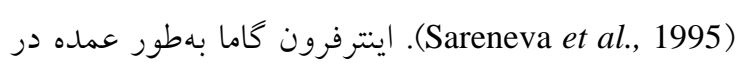
درمان سندرم نقص بيمارى مادرزادى، ليشمانيا؟،

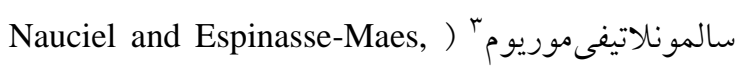

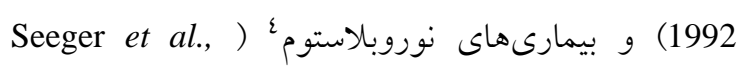

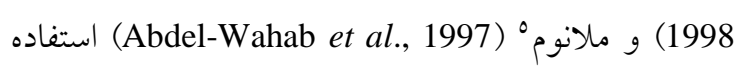

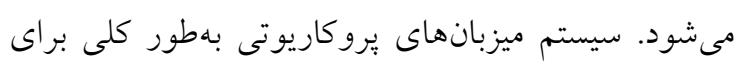

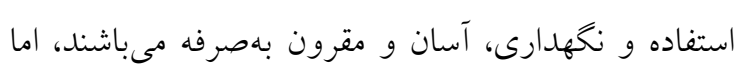

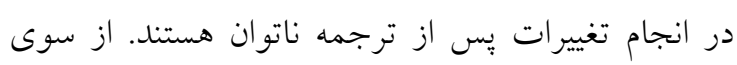

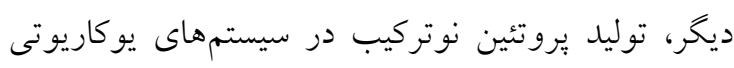
بسيار ترهزينه مى باشد (Yin et al., 2007).

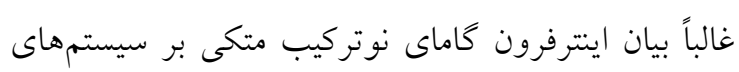

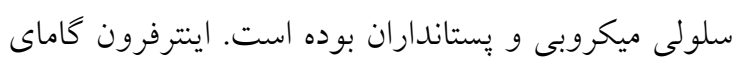

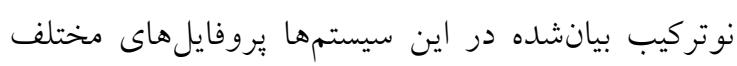

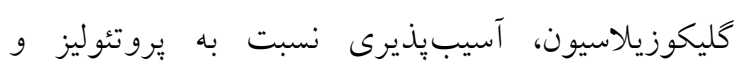

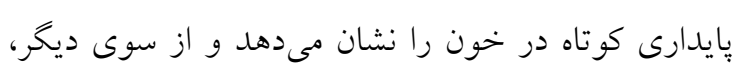
هزينهاى توليد آنها بالا مىباشد (Chen et al., 2004).

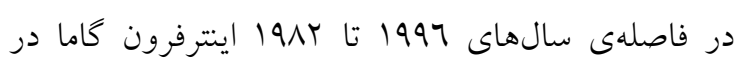

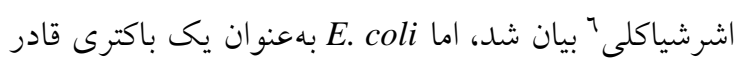

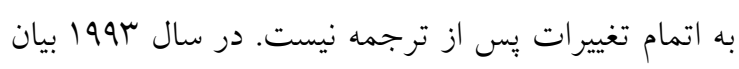

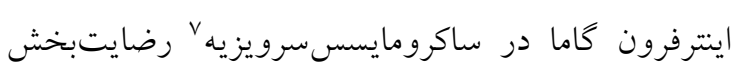

\footnotetext{
1. Natural killer

2. Leishmania

3. Salmonella Typhimurium

4. Neuroblastoma

5. Melanoma

6. E. coli

7. Saccharomyces cerevisiae
} 
Forward primer: 5'-GATAGCAA ACT AGT CAC CAC CAC CAC CAC CAC CAG GAC CCA TAT GTA AAA GAA GCA G-3'

Reverse primer 5'-TATATATA TGT ACA ACG CGT GCG GCC CTC GAT CTG GGA TGC TCT TCG ACC TCG AAA C-3

ياسميد pCAMBIA1305.1 با استفاده از كيت شركت Bioneer استخراج و بس از هضم آنزيمى با آنزيمهاى برشى SpeI و BsrGI، با استفاده از كيت استخراج از زل شركت Bioneer تخليص شد. زن IFN آغازگرهاى اختصاصى تكثير و هضم آنزيمى مذكور انجام شد. سبس محصول واكنش هضم با استفاده از كيت PCR Purification اتصال با ناقل برش خورده با استفاده از آنزيم T4 DNA Ligase pCAMBIA1305.1-IFN به سلولهاى مستعد E.coli به به روش شوك حرارتى انجام گرفت. بهمنظور شناسايى كلونىهاى مثبت، بر روى كلونىهاى رشد كرده در محيط كزينشخ (حاوى كانامايسين)، Colony PCR انجام و كلونى هاى مثبت انتخاب شده با هضم آنزيمى مورد بررسى قرار كرفته و تأييد شدند.

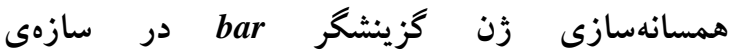
PCAMBIA1305.1-IFN $\gamma$ بهمنظور تكثير زن bar دو آغازگر اختصاصى بر اساس توالى موجود در بانك زن (با شماره دسترسى

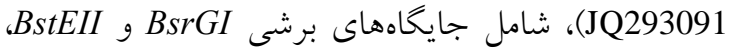
توالى His Tag و لينكر GPGP، طراحى و توسط شركت تكايوزيست سنتز شد. توالى آغازگرهاى زن bar به شرح زير مىباشد:

Forward primer: 5'-TATATATA TGT ACA GGC CCT GGC CCT ATG AGC CCA GAA CGA CGC CCG GCC GAC ATC-3'

Reverse primer 5'-GAGATATC GGTCACC TTA GTG GTG GTG GTG GTG GTG AAT CTC GGT GAC GGG CAG GAC-3

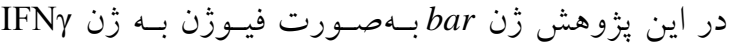

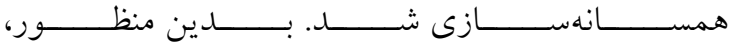

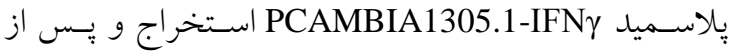

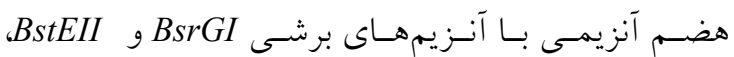
تخليص شد. زن bar با استفاده از آغازگرهاى اختصاصى
و وبرنج (De-Block et al., 1995) استفاده از انتقال بهواسطه اخروباكتريوم بهدست آمده است. بايد توجه كرد كه آنزيم فسفينوتريسين -N- استيل ترانسفراز' در محصولات تراريخت يتانسيل بسيار پِايينى به لحاظ آلرزيك و سمى بودن دارد كه اين بهواسطه، خصوصيات فيزيولوزيك اين آنزيم (تجزيه سريع در شرايط گوارشى يستانداران و فقدان پِيدارى در گرما)، غلظت يايين در بافتهاى گياهى و محصولات غذايى حيوانات اهلى و نهايتاً فقدان همولوزى توالى آمينواسيدى اين آنزيم با بروتئينهاى سمى و آلرزيك، مىباشد) Metz .(et al., 1998 اين تحقيق اولين گزارش از همسانهسازى زن اينترفرون كاماى انسانى بهصورت فيوزن با زن گزيشخر bar در ناقل pCAMBIA1305.1 در ايران است. با توجه به ارزش دارويى يروتئين IFN در يزشكى و نيز اهميت زن كزينشخر bar، يزوهش حاضر با هدف همسانهسازى زن IFN pCAMBIA1305.1 انجام شد تا امكان انتقال سازه حاصل به گياه توتون فراهم گردد.

مواد و روش ها در اين يزوهش از ناقلهاى pRSET داراى زن IFN

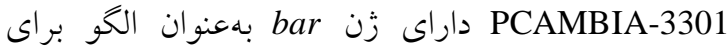
تكثير اختصاصى زنهاى IFNy و bar در واكنش PCR و از ناقل pCAMBIA1305.1 براى همسانهسازى اين زنها | - استفاده شد.

همســانهســازى زن IFNy در ناقــل بيــانى گيــاهى pCAMBIA1305.1 بهمنظور تكثير زن IFNy دو آغازگر اختصاصى بـر اسـاس

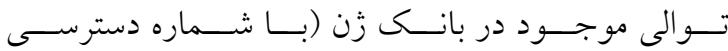
BsrGI و SpeI (NM_000619.2، شامل جايخاههاى برشى ، توالى His Tag و جايشاه يروتئازى فـاكتور Xa، طراحسى و توسط شركت تكايوزيست سنتز شد. توالى آغازگرهـاى زن IFN به شرح زير مىباشد:

1. Phosphinothricin N- acetyl transferase 
اكروباكتريوم تومهفاسينس ب سويه LBA4404 در بردارنده

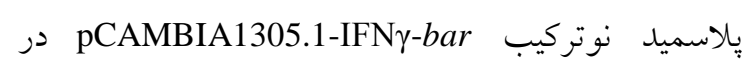

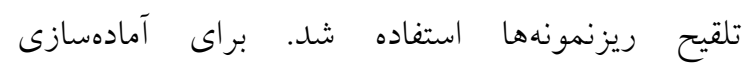

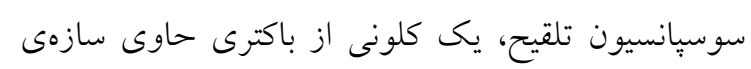

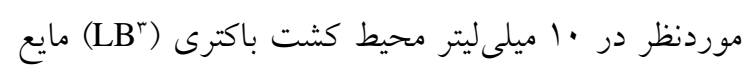

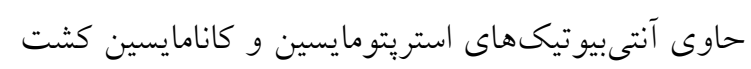

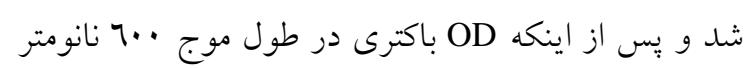

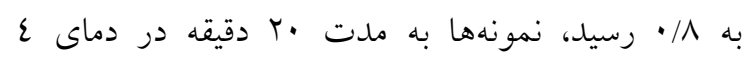

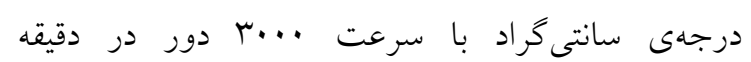
سانتريفيوز شدند. سبس رسوب باكترىها در محيط تلقيح

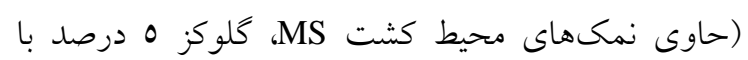

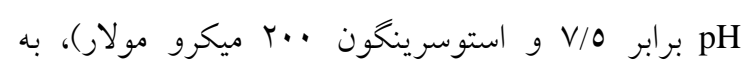

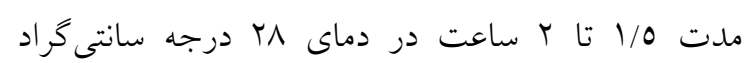

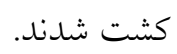

تراريختى سلولهاى گياه توتون با استفاده از اكروباكتر يوم تراختي

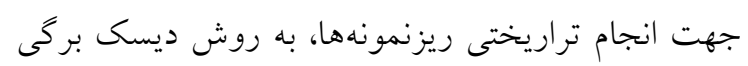

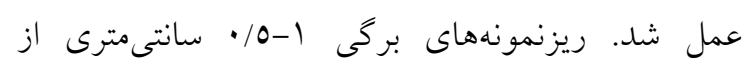

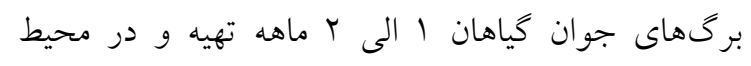
تلقيح به مدت ·لم دقيقه غوطهور شدند. ريزنمونه الهاى بركى تلقيح شده به مدت ب ب روز در محيط هم كشت شامل

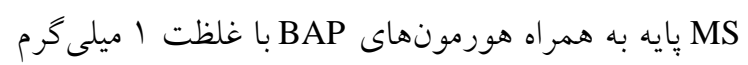

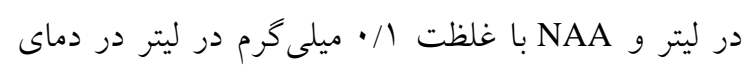
TO درجهى سانتى گراد در شرايط تاريكى قرار كرفتند.

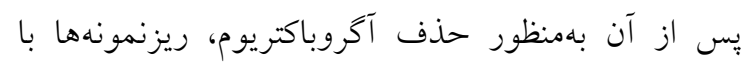

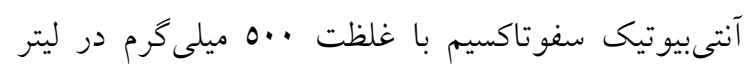

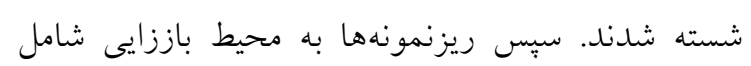

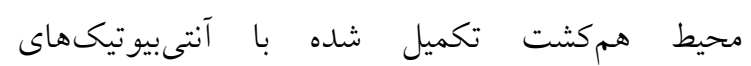

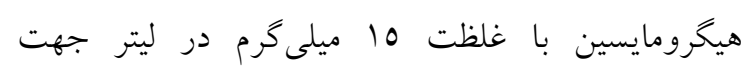

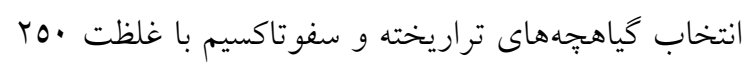
ميلى گرم در ليتر جهت حذف اكروباكتريوم، انتقال داده و

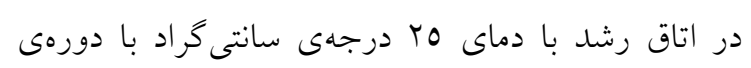

2. A. tumefaciens

3. Luria Bertani broth
تكثير و هضم آنزيمى با همان آنزيمهاى برشى انجام شـــ. سبس محصول واكنش هضم تخليص و در واكنش اتصال

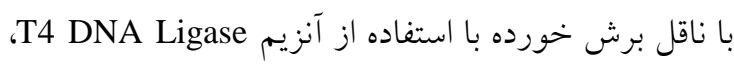

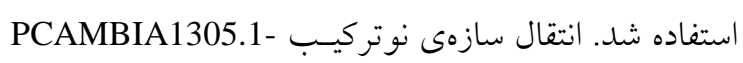

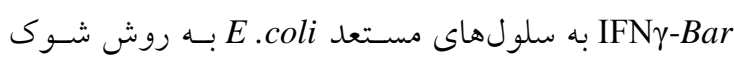
حرارتى انجام گرفت. بهمنظور شناسايى كلونى هاى مثبـت،

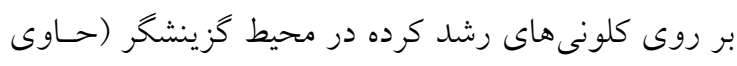

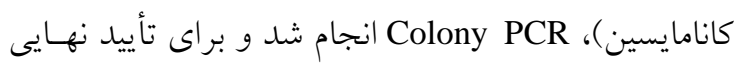

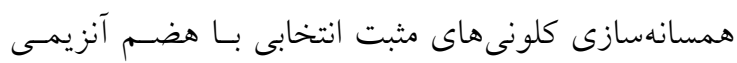

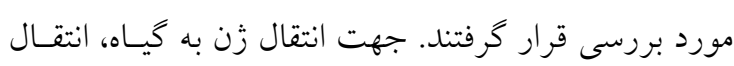

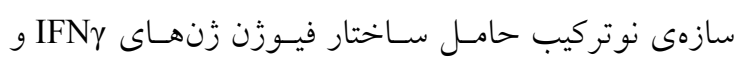

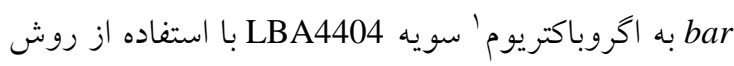
انجمـاد و ذوب (Sambrook and Russel, 2001) انجـام شد و جهت تأييد نهايى حضور ناقـل بيـانى نوتركيـب در باكترى از تكنيكCOlony PCR استفاده شد.

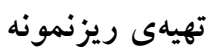

(Nicotiana tobaccum cv. در اين تحقيق از كياه توتون ونونهون جanthi)

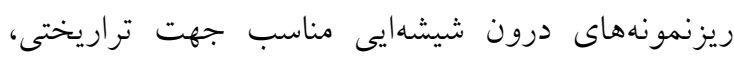

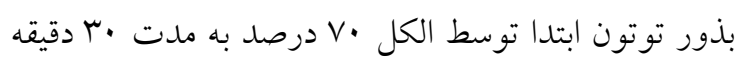

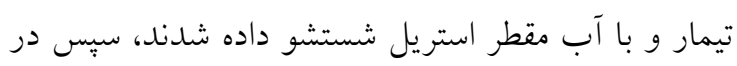

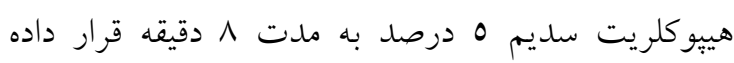

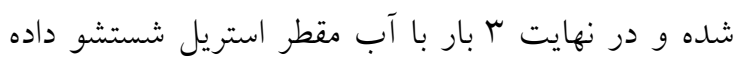

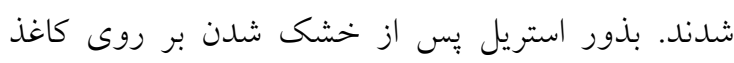
صافى استريل، در محيط MS كامل (شركت Duchefa)

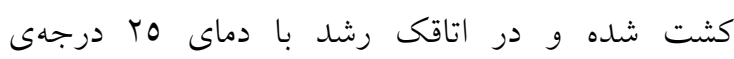

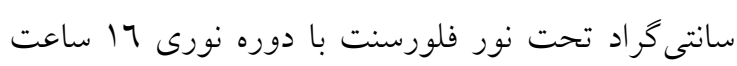

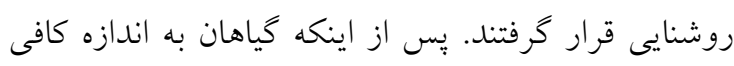

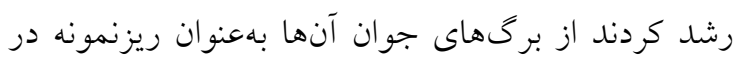
فر آيند تراريختى استفاده شد.

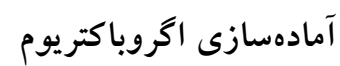


زن IFN با استفاده از بِلاسميد pRSET بهعنوان الكو و آغازكرهاى اختصاصى تكثير شد. محصول PCR بهدست

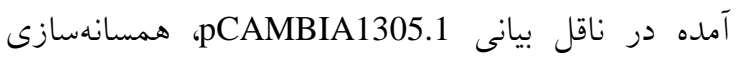

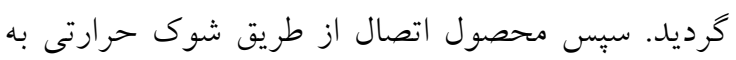

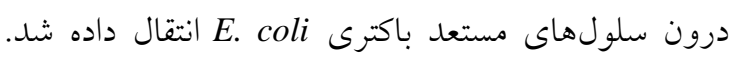
جهت تأييد كلونىهاى رشد كرده بر بر روى من محيط

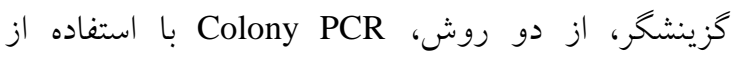
آغاز گرهاى اختصاصى زن IFN

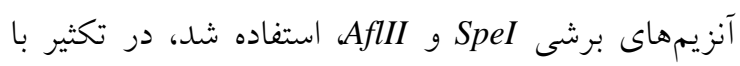

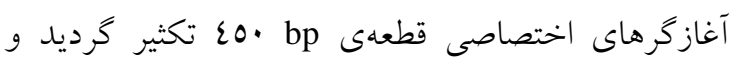

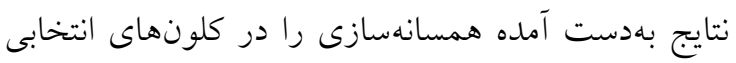
تأييد نمود. تأييد نهايى بر حضور زن زنايج ايتترفرون كاما در

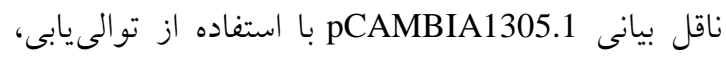

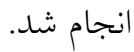

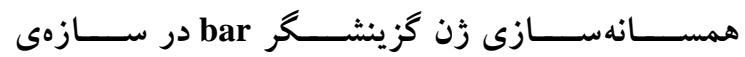
pCAMBIA1305.1-IFN $\gamma$ زن par با استفاده از مِلاسميد pCAMBIA3301 بهعنوان

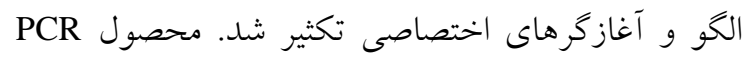
بهدست آمده در ناقل بيانى pCAMBIA1305.1-IFNy بين دو جايخاه برشى SpeI و BstEII، بعد از توالى افزايش دهندهى بيانى ايتترونى كاتالاز همسانهسازى گرديد (شكل

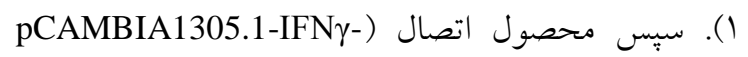
(bar باكترى E. coli انتقال داده شد. جهت تأييد كلونى آنداى

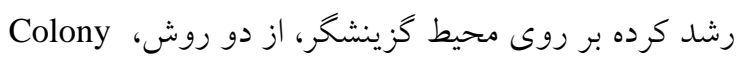

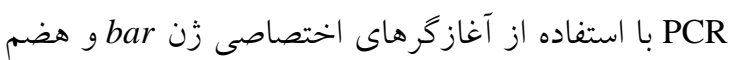

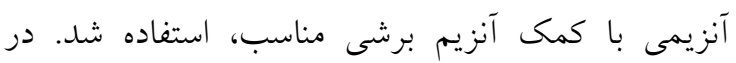

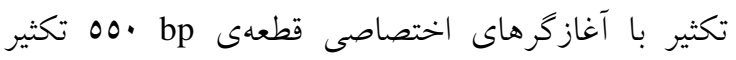
كرديد و همسانهسازى را در كلونهاى انتخابى تأييد نمود.

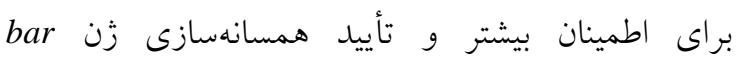
بهصورت فيوزن با زن IFN I در اين سازه، تكنيك

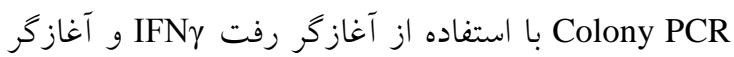

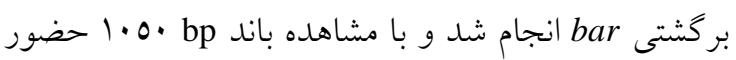
فيوزن IFN در سازه pCAMBIA1305.bar تائيد شد

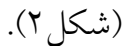

نورى 17 ساعت روشنايى و 1 ساعت تاريكى تحت نور فلورسنت سفيد قرار كرفتند. واكشت ريزنمونههاى باززايى شده هر دو هفته در محيطهاى گزينشكر مشابه

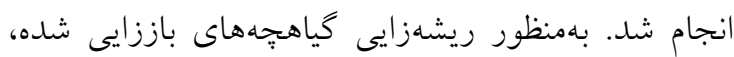

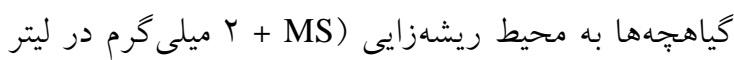

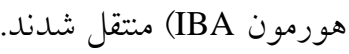
استخراج DNA و آناليز PCR جهت تعيين حضور احتمالى زن هدف در زنوم خياهان

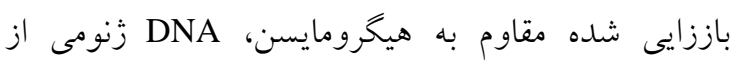
برگهاى جوان اين كياهجهها همراه با كياهان مادرى غيرتراريخته، به روش CTAB استخراج شد. بهمنظور تأييد حضور ترانسزن، آزمون PCR با استفاده از

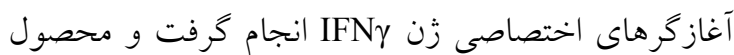
از طريق الكتروفورز در زل آكارز ا درصد تفكيك PCR

$$
\text { استخراج بروتئين و آناليز داتبلات }
$$

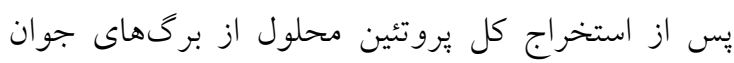

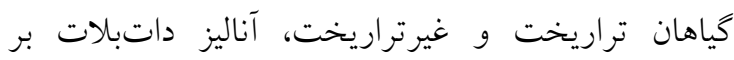
اساس دستورالعمل شركت Roche انجام شد. به اين

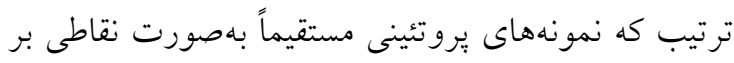

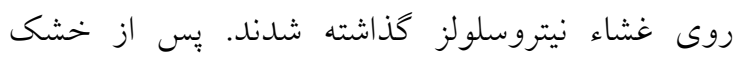
شدن، محلولwestern blocking 1X اضافه و به مدت النداء ساعت در دماى Y - 10 درجهى سانتى گراد انكوبه شد. محلول قبلى را دور ريخته و Anti-His6 Peroxidase جايخزين نموده و به مدت •9 دقيقه انكوبه شد. سبس رونس

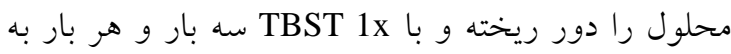
مدت م دقيقه شسته شد. در نهايت سوبستراى آنتى هيستيدين (شركت Roche) را اضافه نموده و پِ از از ظهور رنغ، غشاء نيتروسلولزى با آب مقطر شسته شد و نمونههاى تراريخت و غيرتراريخت ارزيابى شدند.

\section{نتايج و بحث}

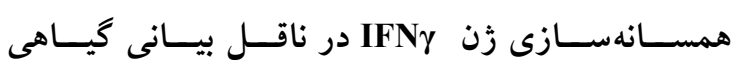

pCAMBIA1305.1 


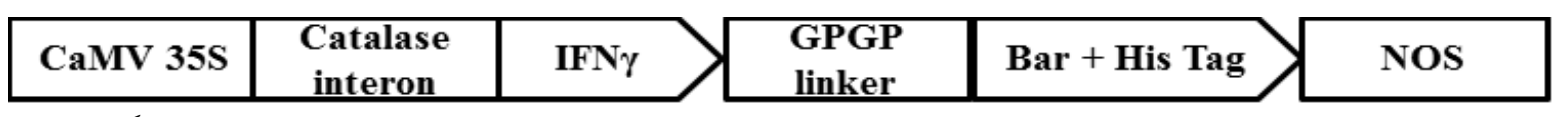

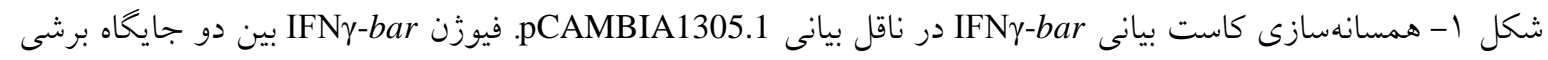

SPeI و و BstEII بعد از توالى افزايش دهندهى بيانى ايتترونى كاتالاز همسانهسازى شده است

Figure 1. Cloning of IFN $\gamma$-bar fusion in pCAMBIA1305.1 expression vector. The IFN $\gamma$-bar has been cloned between the SpeI and BstEII restriction sites and downstream of the catalase intron

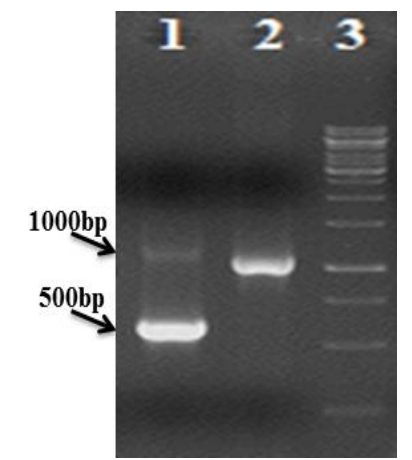

شكل r- تائيد حضور فيوزن IFNy-bar در سازه PCAMBIA1305.1: جاهك ا: باند •00 نتيجه تكثير با استفاده از

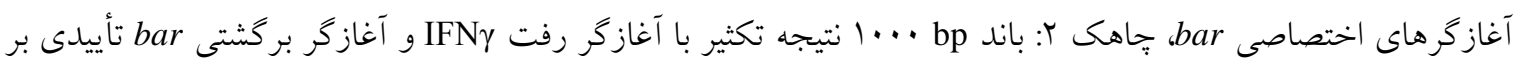

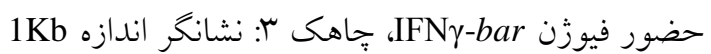

Figure 2. Confirmation of the presence of IFN $\gamma$-bar fusion in pCAMBIA1305.1. 1: The $550 \mathrm{bp}$ fragment of bar gene. 2: The $1000 \mathrm{bp}$ fragment of IFN $\gamma$-bar fusion. 3: One kb DNA marker

$$
\text { DNA آناليز گياهان تراريخت در سطح }
$$

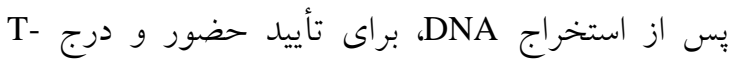
حاوى فيوزن DNA حاصل از تلقيح، آناليز PCR با استفاده از آغازگرَهاى

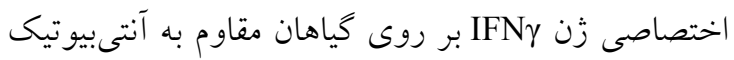

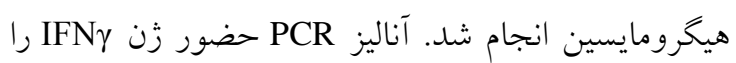

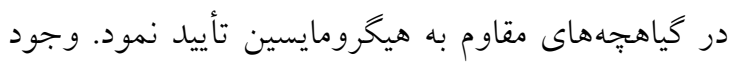

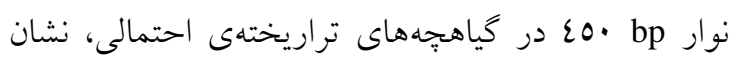

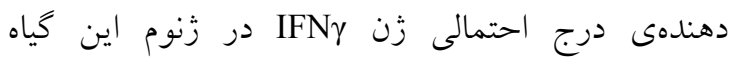

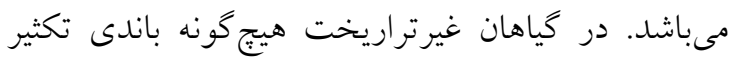

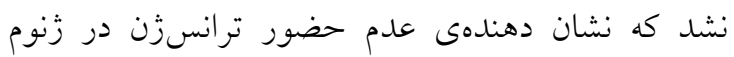

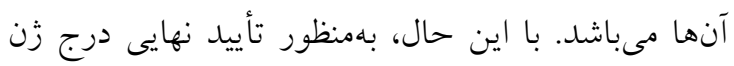

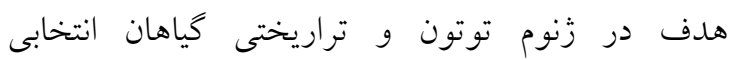
آناليزهاى مناسبترى مورد نياز است.

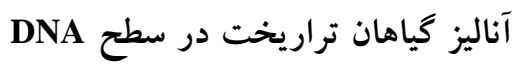

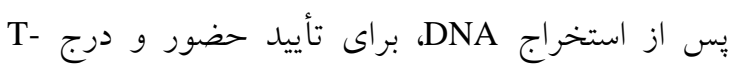
حاوى فيوزن DNA حاصل از تلقيح، آناليز PCR با استفاده از آغازكرهاى
هضم آنزيمى با كمى آنزيم برشى AflII انجام شد (شكل

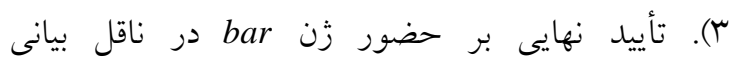
pCAMBIA1305.1-IFN شد. انتقال ناقل بيانى نوتركيب به درون اخروباكتريوم

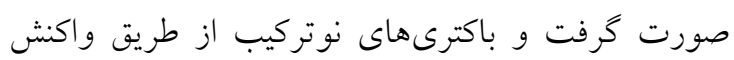
Colony PCR ارزيابى و حضور زن هدف تأييد شد.

انتقال زن فيوزن IFN بعد از تراريخت كردن گياهان توتون، گزينش كياهان تراريخت بر روى محيط حاوى هيخرومايسين انجام شد.

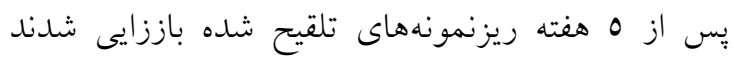
(شكل ع-A و هر سه هفته يكبار بر روى محيط

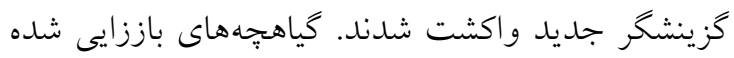

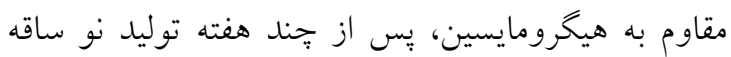

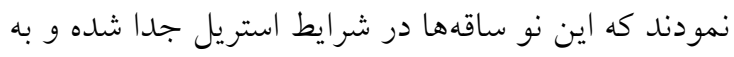
محيط كشت ريشهزايى، براى رشد و ريشهزايى منتقل

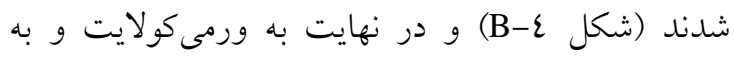

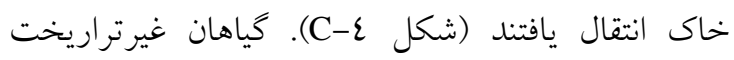

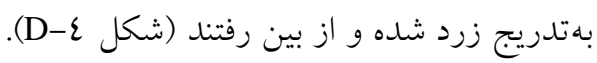


مىباشد. در گياهان غيرتراريخت هيج گونه باندى تكثير

نشد كه نشان دهندهى عدم حضور ترانسزن در زنوم

آنها مىباشد. با اين حال، بهمنظور تأييد نهايى درج زن

هدف در زنوم توتون و تــــراريختى كيــاهان انتخابـى

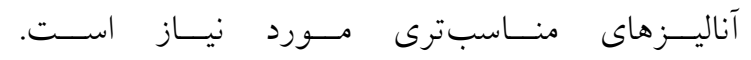

$$
\begin{aligned}
& \text { اختصاصى زن IFN بر روى گياهان مقاوم به آنتىبيوتيك }
\end{aligned}
$$

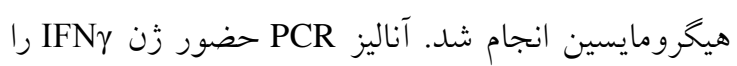

$$
\begin{aligned}
& \text { در كياهجههاى مقاوم به هيخرومايسين تأييد نمود. وجود } \\
& \text { نوار Oع در كياهجههاى تراريختهى احتمالى، نشان } \\
& \text { دهندهى درج احتمالى زن IFN در زنوم اين كياه }
\end{aligned}
$$

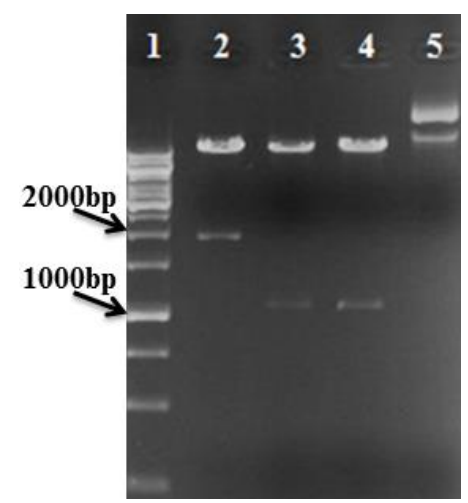

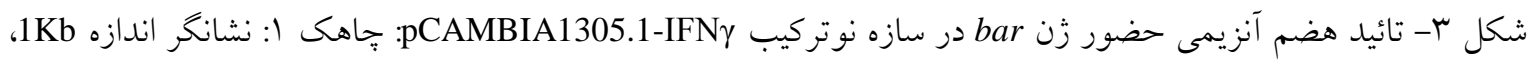

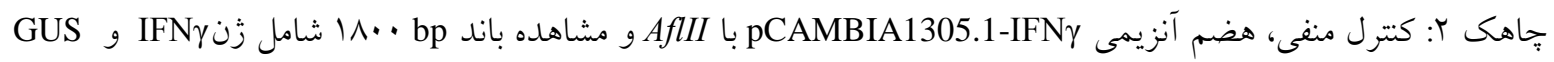

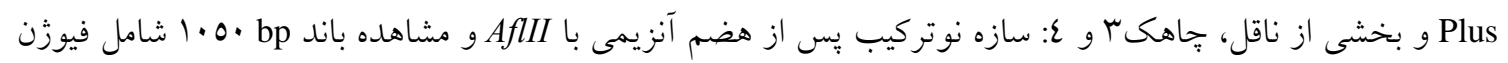

\section{IFN $\gamma$-bar}

Figure 3. The restriction digest confirmation of pCAMBIA1305.1-IFN $\gamma$ construct. 1: One kb DNA marker. 2: Negative control, restriction digest with $A f I I I$, the $1800 \mathrm{bp}$ fragment of IFN $\gamma$ gene, GUS Plus and a section of plasmid. 3, 4: The restriction digest of recombinant construct with $A f l I I$, the $1050 \mathrm{bp}$ fragment of IFN $\gamma$-bar fusion
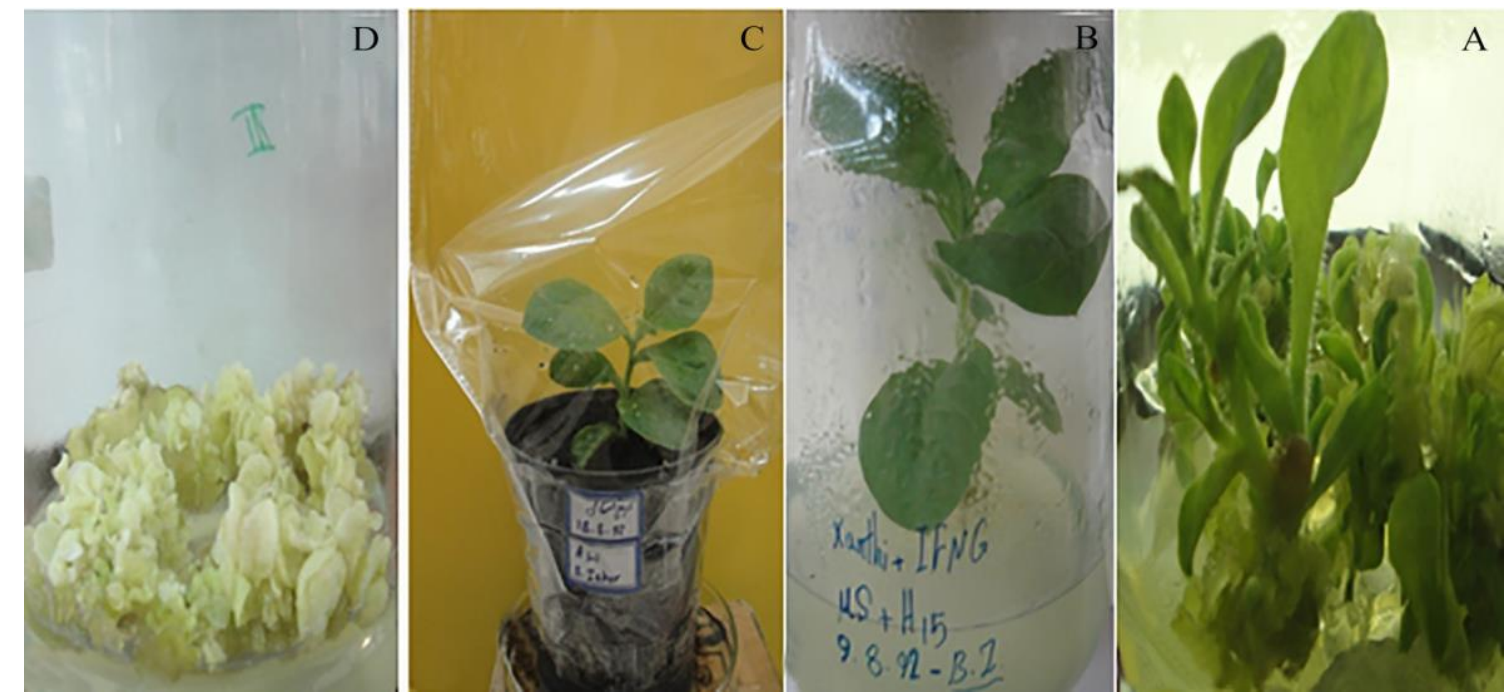

شكل ع- توليد گياهان تراريخته احتمالى از ريزنمونهاى بركى توتون. A) جوانهاى باززايى شده حاوى سازه نوتركيب PCAMBIA1305.1- IFN ب-bar

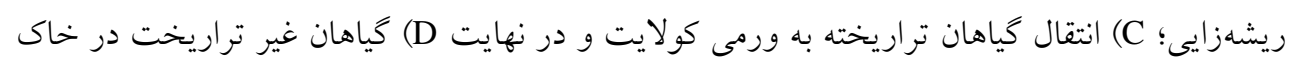

Figure 4. The regeneration of putative transgenic plants from leaf explants of tobacco. A. The regenerated bud on hygromycin selection medium. B. Presumptive transgenic seedlings in rooting medium. C. The putative transgenic in greenhouse 


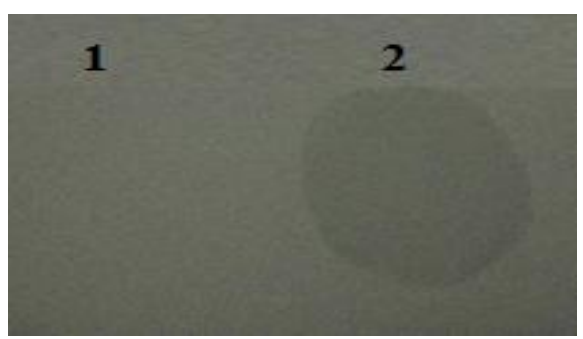

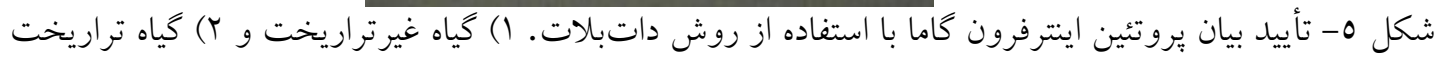
Figure 5. Confirmation of the expression of IFN $\gamma$ protein by dot blot assay. 1) Non-transgenic plant. 2)

Transgenic plant

حداقل رساندن تغييرات ساختارى هر پروتئين، در نظر

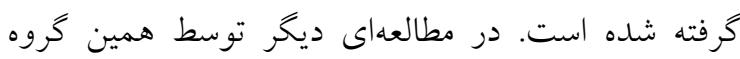

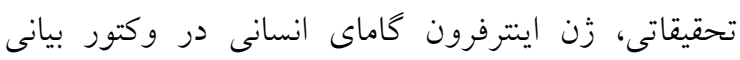

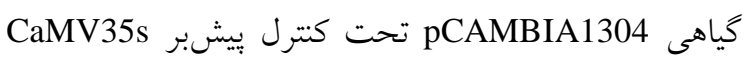

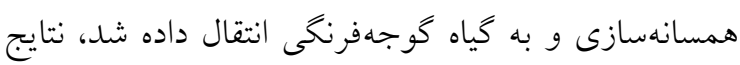

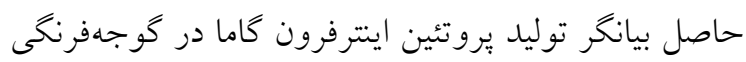

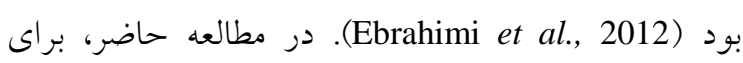
انجام بيان دائم زن از روش ديسك بركى بلهوسيله تلقيح با بال

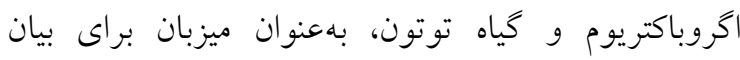

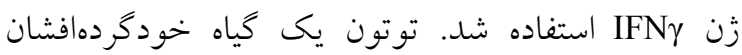
است و علىرغم توليد مواد آلكالوئيدى بهدليل قابليت بيان

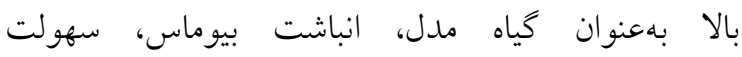
دستكارى، محافظت در برابر آلودگى زنجيره غذايى و ودئون

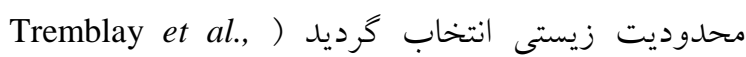

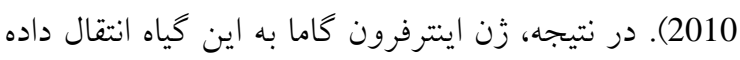

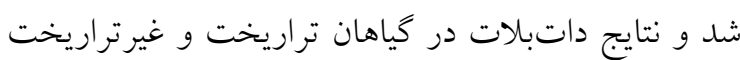

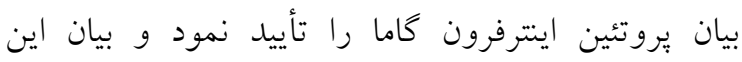
يروتئين با موفقيت در كياه توتون انجام شد. با بائ اين حال مطالعات بيشترى در زمينهى بهينهسازى توليد ايتترفرون

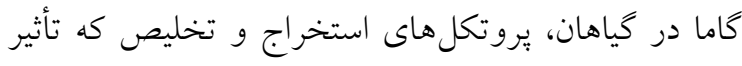
قابل توجهى بر عملكرد نهايى دارند، مورد نياز است. كليد

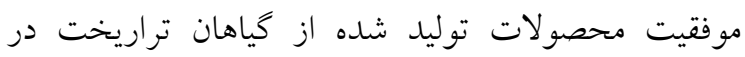

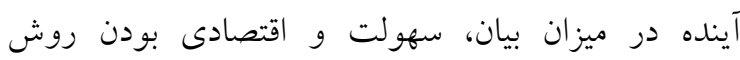

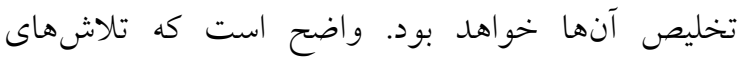
موجود در اين زمينه بايد در جهت بالاتر بردن سطوح بيان

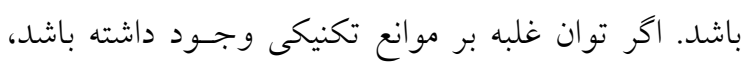

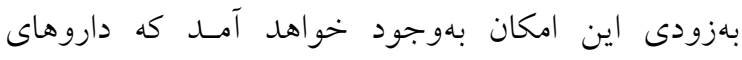

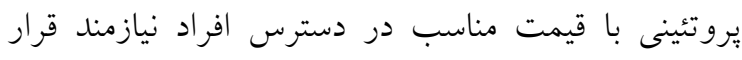

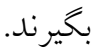

آناليز گياهان تراريخت در سطح بروتئين: براى اطمينان

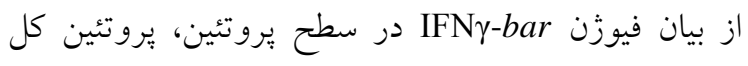

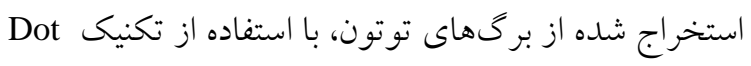

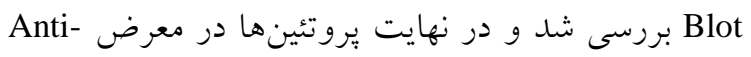

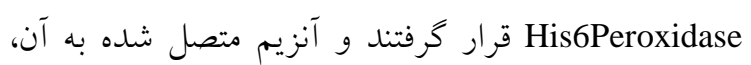
در واكنش با سوبستراى مصرفى تغيير رنخ داد و و بيان يروتئين فيوزن IFN

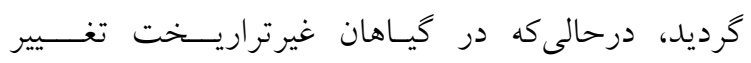
رنــــى مشاهده نشد (شكل 0). در اين مطالعه از وكتور

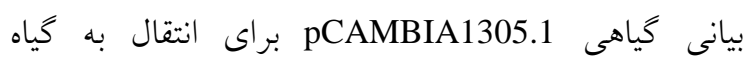

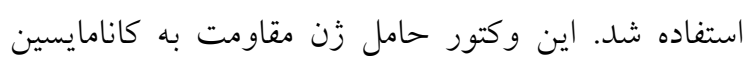

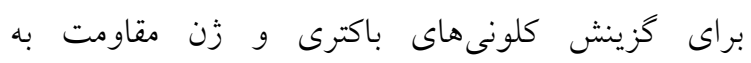

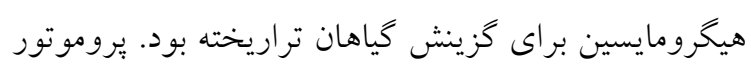
CaMV35s

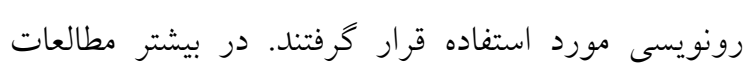

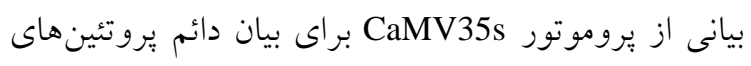

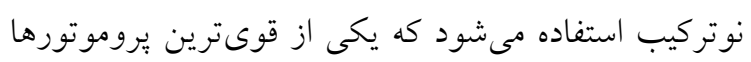

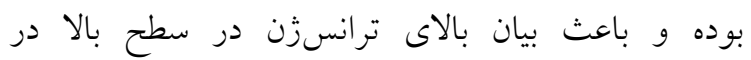

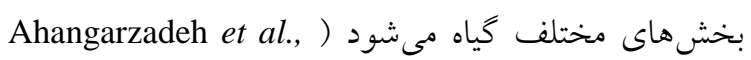

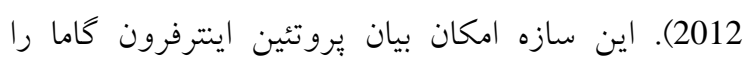

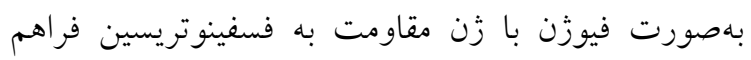

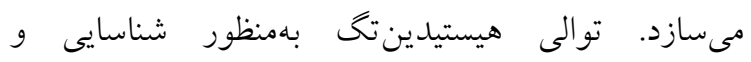

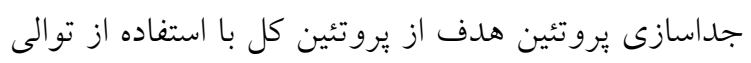

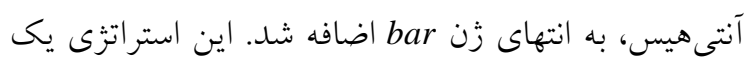

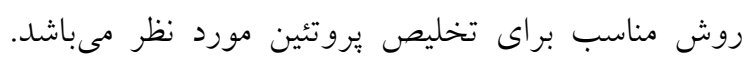

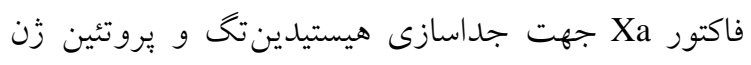
مقاومت به علفكش، از يروتئين تخليصى موردنظر

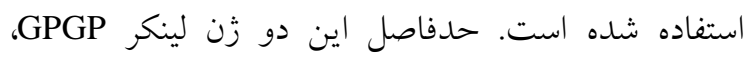

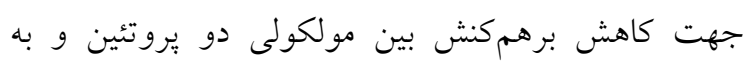




\section{References}

Abdel-Wahab, Z., Weltz, C., Hester, D., Pickett, N., Vervaert, C., Barber, J.R., Jolly, D. and Seigler, H.F. (1997). A phase I clinical trial of immunotherapy with interferon- gene-modified autologous melanoma cells: monitoring the humoral immune response. Cancer, 80: 401-412.

Ahangarzadeh, S.H., Daneshvar, M.H., Rajabi-Memari, H., Galehdari, H. and Alamisaied, K.H. (2012). Cloning, transformation and expression of human interferon $\alpha 2 \mathrm{~b}$ gene in tobacco plant (Nicotiana tobaccum cv. xanthi). Jundishapur Journal of Natural Pharmaceutical Products, 7: 111-116.

Azhdari, H. (2009). Cloning and transformation of human gamma interferon gene to tobacco plants, M.Sc. Thesis, Tarbiat Modarres University, Tehran, Iran (In Persian).

Bagheri, K.H. (2009). Oleosin gamma interferon gene transfer to canola and study of transgenic plants, Ph.D. Thesis, Tarbiat Modarres University, Tehran, Iran (In Persian).

Chen, T.L., Lin, Y.L., Lee, Y.L., Yang, N.S. and Chan, M.T. (2004). Expression of bioactive human interferon-gamma in transgenic rice cell suspension cultures. Transgenic Research, 13: 499-510.

Davoudi, N., Hemmati, A., Khodayari, Z., Adeli, A. and Hemayatkar, M. (2011). Cloning and expression of human ifn-gamma in leishmania tarentolae. World Journal of Microbiology and Biotechnology, 27:1893-1899.

De-Block, M., De Sonville, A. and Debrouwer, D. (1995). The selection mechanism of phosphinothricin is influenced by the metabolic status of the tissue. Planta, 197: 619-626.

D'Halluin, K., De-Block, M. and Denecke, J. (1992). The bar gene as selectable and screenable marker in plant engineering. Methods in Enzymology, 216: 415-426.

Ebrahimi, N., Rajabi-Memari, H., Ebrahimi, M.A. and Roayaei Ardakani, M. (2012). Cloning, transformation and expression of human gamma interferon gene in tomato (Lycopersicon esculentum mill.). Biotechnology and Biotechnological Equipment, 26: 2925-2929.

Falco, M.C., Neto, A.T. and Ulian, E.C. (2000). Transformation and expression of a gene for herbicide resistance in a brazilian sugarcane. Plant Cell Reports, 19: 1188-1194.

Horn, M.E., Woodard, S.L. and Howard, J.A. (2004). Plant molecular farming: systems and products. Plant Cell Reports, 22: 711-20.

Kim, J.K., Duan, X. and Wu, R. (1999). Molecular and genetic analysis of transgenic rice plants expressing the maize ribosome-inactivating protein b-32 gene and the herbicide resistance bar gene. Molecular Breeding, 5: 85-94.

Ma, J.K., Drake, P.M. and Christou, P. (2003). The production of recombinant pharmaceutical proteins in plants. Nature Reviews Genetics, 4: 794-805.

Metz, P.L.J., Stiekema, W.I. and Nap, J.P. (1998). A transgene-centered approach to the biosafety of transgenic phosphinothricin-tolerant plants. Molecular Breeding, 4: 335-341.

Nauciel, C. and Espinasse-Maes, F. (1992). Role of gamma interferon and tumor necrosis factor alpha in resistance to salmonella typhimurium infection. Infection and Immunity, 60:450-454.

Sambrook, J. and Russel, D.W. (2001). Molecular cloning, a laboratory manual. Cold Spring Harbour Laboratory Press, Cold Spring Harbour, New York, USA.

Sareneva, T., Pirhonen, J., Cantell, K. and Julkunen, I. (1995). N-glycosylation of human interferon-gamma: glycans at Asn-25 are critical for protease resistance. Biochemical Journal, 308: $9-14$

Seeger, R.C., Rosenblatt, J.D., Duerst, R.E., Reynolds, C.P., Villablanca, J.G., Hasenauer, B. and Feig, S.A. (1998). A phase i study of human gamma interferon gene-transduced tumor cells in patients with neuroblastoma. Human Gene Therapy, 9: 379-390.

Spencer, T.M., Gordon-Kamm, W.J., Daines, R.J., Start, W.G. and Lamaux P.G. (1990). Bialaphos selection of stable transformants from maize cell culture. Theoretical and Applied Genetics, 79: 625-631.

Taheri-Javan, N. (2008). Transformation human gamma IFN gene to canola and regeneration of the transgenic plants, M.Sc. Thesis, Tarbiat Modarres University, Tehran, Iran (In Persian).

Thampson, C.H., Movva, N.R., Tizard, R., Crameri, R., Deivies, E.M., Lauwereys, M. and Botterman, J. (1987). Characterization of the herbicid-resistance gene bar from Streptomyces hygroscopicus. The EMBO Journal, 6: 2519-2523.

Tremblay, R., Wang, D., Jevnikar, A.M. and Ma, S.H. (2010). Tobacco, a highly efficient green bioreactor for production of therapeutic proteins. Biotechnology Advances, 28: 214-221.

Yin, J. and Li, G. (2007). Select what you need: a comparative evaluation of the advantages and limitations of frequently used expression systems for foreign genes. Journal of Biotechnology, 127: 335-47.

Zamani, A., Pour-Jafari, H., Elahi, S.M., Moghadam-Nazem, N. and Massie, B. (2006). Inducible expression of human gamma interferon. Iranian Biomedical Journal, 10: 197-202. 


\title{
Cloning, Transformation and Stable Expression of a Fusion of Human Interferon Gamma and bar Genes in Tobacco Plant (Nicotiana tobaccum cv. xanthi)
}

\section{Bahareh Zakerghoran ${ }^{1}$, Hamid Rajabi Memari ${ }^{2, *}$, Daryoosh Nabati Ahmadi ${ }^{2}$ and Marzieh Siahmard ${ }^{3}$}

1- M.Sc. Student, Department of Agronomy and Plant Breeding, Faculty of Agriculture, Shahid Chamran University, Ahwaz

2- Assistant Professor, Department of Agronomy and Plant Breeding, Faculty of Agriculture, Shahid Chamran University, Ahwaz

3- M.Sc. Student, Department of Agronomy and Plant Breeding, Ramin Agriculture and Natural Resources University, Ahwaz

(Received: October 7, 2013 - Accepted: February 3, 2014)

\begin{abstract}
The production of human gamma interferon in eukaryote expression systems refers as a therapeutic recombinant protein which has significant impact in medical studies. Unique com position of gamma interferon makes such protein as a suitable tool against cancer. It is documented that phosphinothricin (PPT) classified as non-selective herbicide group of bialaphos acts an inhibitor for glutamine synthetase. The bar gene is encoding the phosphinothricin-N-acetyltransferase (PAT) enzyme. This enzyme capable of boosting resistance against PPT herbicide, thus it can be selected as a selective marker within plant population. Then various colony PCR techniques, enzymatic digestion and sequencing were used to confirm the accuracy of fusion of IFN $\gamma$-bar gens within expression transporter. Using freezing and thawing method to transfer the pCAMBIA1305.1- IFN $\gamma$-bar construction into strain of LBA4404 of agrobacterium, then disc leaves was used to integrate into the genomic of tobacco plant. The transgenic plants were selected under selector condition which possess $30 \mathrm{mg} / \mathrm{l}$ of hygromycin. After the developed roots were transferred into soil, and PCR technique was used to confirm the presence of IFN $\gamma$-bar in the genomic of plants. Dot blot analysis was applied to detect IFN $\gamma$-bar protein in transgenic of to tobacco plants.
\end{abstract}

Keywords: Human interferon gamma, Stable expression, Tobacco plant, bar gene 